\title{
Follicular size affects the meiotic competence of in vitro matured prepubertal and adult oocytes in sheep
}

\author{
Sergio Ledda*, Luisa Bogliolo, Giovanni Leoni, \\ Salvatore Naitana
}

Department of Animal Biology, Veterinary Faculty, via Vienna 2, 07100 Sassari, Italy

(Received 28 December 1998; accepted 24 March 1999)

\begin{abstract}
Non-atretic follicles dissected from prepubertal and adult ovaries were allocated in three groups: a) < 1 mm; b) 1-2 mm; c) $>2 \mathrm{~mm}$. After $24 \mathrm{~h}$ of maturation, a lower percentage of adult oocytes from group a $(P<0.01)$ reached metaphase II than those from groups $\mathrm{b}$ and $\mathrm{c}(70.4$ versus 89.5 and 95.5$)$. Prepubertal oocytes showed similar results $(P<0.01 ; 27.2$ versus 79.8 and 81.8$)$. There was a significant difference $(P<0.01)$ in meiotic progression between prepubertal and adult oocytes of $<1 \mathrm{~mm}$ follicles. The diameter of prepubertal oocytes derived from group a was significantly lower $(P<0.01)$ compared to groups b and c (138.1 versus 142.1 and 145.6$)$; adult oocytes showed similar results $(P<0.01 ; 142.2$ versus 157.2 and 158.1$)$. Oocytes with the same diameter derived from different follicles of prepubertal and adult ovaries showed similar meiotic progression rates. (C) Inra/Elsevier, Paris
\end{abstract}

ovary / oocyte / follicle size / meiotic competence / adult and prepubertal sheep

Résumé - Lien entre la taille et la compétence méiotique d'ovocytes d'agnelles et de brebis maturés in vitro. Des follicules non-atrétiques sélectionnés à partir d'ovaires d'ovins prépubères et adultes ont été répartis en trois groupes selon leur diamètre : a) $<1 \mathrm{~mm}$; b) $1-2 \mathrm{~mm}$; c) $>2 \mathrm{~mm}$. Après 24 $\mathrm{h}$ de maturation les ovocytes dérivant des ovaires d'animaux adultes appartenant au groupe a ont atteint la MII dans des pourcentages nettement inférieurs $(p<0,01)$ à ceux observés pour les groupes b et c $(70,4$ versus 89,5 et 95,5$)$. Des résultats identiques ont été obtenus avec les ovocytes provenant d'animaux prépubères $(p<0,01 ; 27,2$ versus 79,8 et 81,8$)$. Une grande différence $(p<0,01)$ dans le potentiel à reprendre la méiose existe entre les ovocytes de prépubères et des adultes provenant de follicules $<1 \mathrm{~mm}$. Le diamètre des ovocytes d'agneaux provenant de follicules du groupe a était nettement inférieur $(p<0,01)$ par rapport à ceux provenant de follicules des groupes b ou c (138,1 versus 142,1 et 145,6$)$. Des résultats identiques ont été observés pour les ovocytes provenant d'animaux adultes $(p<0,01,142,2$ versus 157,2 et 158,1). Des ovocytes de même diamètre provenant d'ovaires de prépubères et d'adultes ne diffèrent pas dans leur aptitude à reprendre la méiose. (C) Inra/Elsevier, Paris

follicule / ovocyte / compétence méiotique / ovins prépubères et adultes

* Correspondence and reprints

E-mail: vetfis@ssmain.uniss.it 


\section{INTRODUCTION}

It is known that mammalian oocytes released from the inhibitory influences of their follicles and cultured in vitro under efficient conditions are able to spontaneously resume meiosis and complete maturation [10]. Several data indicate, however, that many of these oocytes fail to be fertilised, develop or produce a high percentage of viable embryos [12, 18, 29]. During oocyte growth, physiological events occur in both the nucleus and the cytoplasm allowing the oocyte to achieve final developmental competence. Nuclear progression from the germinal vesicle (GV) to the metaphase II (MII) stage can occur in oocytes that may not have undergone complete cytoplasmic maturation [2]. Many intracellular changes are required in the cytoplasm, such as organelle distribution $[28,29]$ and protein synthesis at different stages of meiosis progression $[15,22]$. Moreover, the meiotic competence in bovine species is closely related to the follicular dimension; oocytes derived from small follicles showed a lower capacity to resume meiosis and to develop up to early embryonic stages [4]. Previous works [8, 19,23 ] have clearly demonstrated that the acquisition of meiotic competence after in vitro maturation is achieved progressively as the follicular size increases in several domestic species. Oocytes derived from follicles less than $2 \mathrm{~mm}$ in diameter did not resume or complete meiosis in vitro.

In sheep, Moor and Trounson [21] also indicated that meiotic and developmental competence is higher in oocytes recovered from large follicles (atretic and non-atretic) than in those derived from small follicles. They also showed that oocytes cultured in intact follicles $(<2 \mathrm{~mm})$ are incapable of resuming meiosis. A positive correlation between follicular size and meiotic and developmental competence has also been reported by Cogniè et al. [5]. They showed that a different genotype can affect the ability of oocytes recovered from follicles of different sizes to resume meiosis in vitro.
A lower developmental capacity has also been observed after in vitro maturation of oocytes obtained from prepubertal animals $[9,26,27]$. This can be related to defective conditions of oocyte maturation and can also be due to the reduced size of oocytes and follicular population [17] and a small size of volume fractions of mitochondria and cortical granules [25].

The aim of this work was to examine the relationship between the follicular size and meiotic competence of oocytes derived from prepubertal and adult sheep in different categories of follicles after in vitro maturation.

\section{MATERIALS AND METHODS}

\subsection{Recovery of the oocytes}

Ovaries from prepubertal ( $30-40$ days, body mass 6-12 kg) and adult Sarda sheep were collected from a local abattoir and transported in Dulbecco's phosphate-buffered saline (PBS; Sigma, Saint-Louis, MO) containing 50 U penicillin $\mathrm{mL}^{-1}$ and $50 \mu \mathrm{g}$ streptomycin $\mathrm{mL}^{-1}$ (SIGMA) at $20-25^{\circ} \mathrm{C}$, arriving at the laboratory within $1 \mathrm{~h}$. Ovaries were washed three times in fresh PBS with penicillin and streptomycin.

Non-atretic follicles were obtained from the ovaries using microblades and fine forceps under a dissecting microscope and single selected follicles were obtained from both prepubertal and adult ovaries. After dissection, the follicles were measured with a micrometer and placed according to diameter in the three following groups: a) $<1 \mathrm{~mm}$; b) $1.0-2.0 \mathrm{~mm}$; ) $>2 \mathrm{~mm}$. The walls of the follicles of the different groups were opened and the oocytes were released in the TCM 199 medium (with Earle's salts and bicarbonate; Sigma) supplemented with $25 \mathrm{mmol}$ Hepes $\mathrm{I}^{-1}$ (Sigma), penicillin and streptomycin, and $0.1 \%$ (w/v) polyvinyl alcohol (PVA; Sigma). The cumulus-oocyte complexes (COCs), selected according to morphological criteria (intact $\mathrm{COCs}$ with several dense cumulus cell layers and homogeneous cytoplasm), were released in the medium and washed three times in the same medium before in vitro maturation.

After denudation of the cumulus cells by mechanical pipetting, several oocytes obtained from each follicle-sized group of prepubertal and adult sheep, including the zona pellucida, were 
measured using an inverted microscope equipped with a calibrated eyepiece. Their outside diameters were recorded.

\subsection{In vitro maturation}

The COCs obtained from juveniles were allocated to the following maturation system: prepubertal and adult oocytes were cultured in parallel for $24 \mathrm{~h}$ in TCM 199 medium supplemented with $10 \%(\mathrm{v} / \mathrm{v})$ heat-treated foetal calf serum (FCS; Sigma) in the presence of $10 \mu \mathrm{g} \mathrm{FSH} \mathrm{mL}{ }^{-1}$ and $10 \mu \mathrm{g} \mathrm{LH} \mathrm{mL}^{-1}$ (Pergonal, Serono, Rome). Only $25-30$ of the oocytes were put in a single Petri dish ( $35 \mathrm{~mm}$ ) containing $2 \mathrm{~mL}$ of the culture medium which was maintained on a rotary shaker at low speed during the entire incubation period to avoid the attachment of granulosa cells to the bottom of the Petri dish. The culture conditions were the following: a humidified atmosphere with $5 \% \mathrm{CO}_{2}$ in the air and a temperature of $39^{\circ} \mathrm{C}$. At the end of the maturation period, the oocytes from each group were fixed for $24 \mathrm{~h}$ in acetic acid ethanol solution $(1: 3, \mathrm{v} / \mathrm{v})$, stained with $1 \%$ (w/v) Lacmoid (Sigma) and examined under a phase-contrast microscope at a magnification of $\times 200-400$. The stages of nuclear maturation were assessed after evaluation, as the germinal vesicle (GV), metaphase I (M I), metaphase II (M II) and degenerated.

Some oocytes from prepubertal ovary $<1 \mathrm{~mm}$ follicles were cultured for $48 \mathrm{~h}$ in the same culture conditions as those described above, examined after $24 \mathrm{~h}$ of fixation and stained with $1 \%$ Lacmoid.

\subsection{Statistical analysis}

Differences in meiotic progression according to the follicular size of prepubertal and adult oocytes were subjected to chi-squared analysis or the Fisher exact test. Mean oocyte diameters in the follicle size categories were compared statistically by ANOVA. Differences were considered significant at $P<0.05$.

\section{RESULTS}

After $24 \mathrm{~h}$ of incubation the percentage of metaphase II oocytes derived from ovaries of adult and prepubertal animals increased progressively according to follicle sizes (from $<1$ to $>2 \mathrm{~mm}$ (table I). There was a significant difference $(P<0.01)$ in the percentage of M II between oocytes derived from $<1 \mathrm{~mm}$ follicles compared to oocytes of $>1$ and $>2 \mathrm{~mm}$ of both prepubertal ( 27.2 versus 79.8 and $81.8 \%$ ) and adult ( 70.6 versus 89.7 and $95.5 \%$ ) sheep. Oocytes collected from $<1 \mathrm{~mm}$ follicles of prepubertal animals also showed a significantly $(P<0.01)$ marked decrease in the ability to resume complete meiosis compared to adult oocytes. This difference can be related to a significantly lower $(P<0.01)$ oocyte diameter in the three categories of follicles $(<1,1-2$ and $>2 \mathrm{~mm}$ ) of prepubertal $(138.1,142.1$ and $145.6 \mu \mathrm{m}$ ) compared to adult sheep $(142.2,157.2$ and $158.1 \mu \mathrm{m})$ (table II).

Table I. Meiotic competence of prepubertal and adult oocytes derived from follicles of different size.

\begin{tabular}{lcccccc}
\hline & $\begin{array}{c}\text { Follicle size } \\
(\mathrm{mm})\end{array}$ & $\begin{array}{c}\text { Oocyte } \\
\text { number }\end{array}$ & \multicolumn{3}{c}{ Stage of meiotic progression in adult oocytes } \\
\cline { 4 - 7 } & & & $\mathrm{GV}(\%)$ & $\mathrm{M} \mathrm{I}(\%)$ & $\mathrm{M} \mathrm{II}(\%)$ & Deg. $(\%)$ \\
\hline Adults & $<1.0$ & 85 & $10(11.7)^{\mathrm{a}}$ & $10(11.7)^{\mathrm{a}}$ & $60(70.6)^{\mathrm{a}}$ & $5(5.4)$ \\
& $1.0-2.0$ & 88 & $--^{\mathrm{b}}$ & $9(10.2)^{\mathrm{b}}$ & $79(89.7)^{\mathrm{b}}$ & - \\
& $>2.0$ & 45 & $--^{\mathrm{b}}$ & $2(4.5)^{\mathrm{b}}$ & $43(95.5)^{\mathrm{b}}$ & - \\
Prepubertal & $<1.0$ & 92 & $25(27.2)^{\mathrm{c}}$ & $37(40.2)^{\mathrm{c}}$ & $25(27.2)^{\mathrm{c}}$ & $5(5.4)$ \\
& $1.0-2.0$ & 94 & $6(6.4)^{\mathrm{d}}$ & $10(10.6)^{\mathrm{a}}$ & $75(79.8)^{\mathrm{b}}$ & $3(3.2)$ \\
& $>2.0$ & 44 & $3(6.8)^{\mathrm{d}}$ & $4(9.1)^{\mathrm{a}}$ & $36(81.8)^{\mathrm{b}}$ & $1(2.3)$ \\
\hline
\end{tabular}

Between columns, test $\chi^{2}$ : a versus $b=P<0.01 ;$ a,b versus $c=P<0.001 ; c$ versus $d=P<0.01$. 
Table II. Oocyte diameter of prepubertal and adult sheep derived from follicles of different sizes.

\begin{tabular}{lccc}
\hline Oocyte & \multicolumn{3}{c}{ Follicle size in both prepubertal and adult sheep } \\
\cline { 2 - 4 } & $<1 \mathrm{~mm}$ & $1-2 \mathrm{~mm}$ & $>2 \mathrm{~mm}$ \\
\hline Adult & $142.2 \pm 3.5 \mu \mathrm{m}^{\mathrm{a}}$ & $157.2 \pm 2.9 \mu \mathrm{m}^{\mathrm{b}}$ & $158.1 \pm 3.1 \mu \mathrm{m}^{\mathrm{b}}$ \\
Prepubertal & $138.1 \pm 2.6 \mu \mathrm{m}^{\mathrm{c}}$ & $142.1 \pm 3.1 \mu \mathrm{m}^{\mathrm{a}}$ & $145.6 \pm 2.4 \mu \mathrm{m}^{\mathrm{d}}$ \\
\hline
\end{tabular}

Test ANOVA: different superscripts are statistically different $(P<0.01)$.

Oocytes derived from $<1 \mathrm{~mm}$ follicle size cultured in vitro for $48 \mathrm{~h}$ showed a similar percentage of $\mathrm{M}$ II as those cultured for $24 \mathrm{~h}$ (29.7 versus 27.2).

\section{DISCUSSION}

This work shows that the ability to progress in the meiotic cycle is achieved progressively as follicle and oocyte diameter increases in both adult and prepubertal sheep. However, in contrast to the observations of De Smedt et al. [8] in goats, sheep oocytes derived from very small follicles $(<1 \mathrm{~mm})$ of adult ovaries can progress in meiosis in a high percentage and $70 \%$ of total oocytes reach metaphase II.

Several studies in other domestic species $[6,11,23]$, indicate that significantly more oocytes derived from $>2 \mathrm{~mm}$ follicles matured in vitro up to $\mathrm{M}$ II, while oocytes collected from follicles of less that $2 \mathrm{~mm}$ are incapable of resuming or completing meiosis. In prepubertal goats it has been reported [20] that complete meiotic competence was achieved in oocytes derived from $3 \mathrm{~mm}$ in diameter follicles and similar results have been obtained in adult goats by De Smedt et al. [8]. They observed that the oocyte was able to resume meiosis in $<1 \mathrm{~mm}$ antral follicles but only oocytes derived from follicles larger than $3 \mathrm{~mm}$ were fully competent and able to reach metaphase II. These authors also showed that oocytes from $2 \mathrm{~mm}$ follicles were still actively engaged in RNA synthesis, whereas RNA synthesis was reduced in oocytes from $3 \mathrm{~mm}$ follicles. Motlik et al. [24] reported that porcine oocytes derived from $<0.7 \mathrm{~mm}$ follicles remained at the germinal vesicle stage maintaining activity in RNA synthesis. The capacity to resume meiosis also seems to be related to the location of the follicles in the ovaries. Arlotto et al. [1] reported that oocytes of all diameters collected from the cortical region of the ovary are significantly more competent than oocytes located in a sub-cortical area. More recently Hyttel et al. [14] showed a direct correlation only between bovine oocyte dimension and meiotic developmental competence after the maturation of oocytes derived from follicles of different sizes.

In sheep, after the culture of intact follicles of different sizes, Moor and Trounson [21] showed that oocytes derived from $<2 \mathrm{~mm}$ follicles were meiotically incompetent while on the contrary oocytes from bigger follicles were meiotically and developmentally fully competent. This is apparently in contrast with the results reported in this paper but our culture conditions were different and oocytes were cultured outside of the follicles and not in intact follicles as Moor and Trounson reported. These conditions may have allowed the oocyte to progress to meiosis because it cannot be influenced by the inhibitory control of meiosis exerted by the follicular environment. Cogniè et al. [5] also found that the ability of ovine oocytes to resume meiosis and to gain the ability to develop up to the blastocyst stage is acquired sequentially as the follicle 
enlarges. They also showed that this ability is related to the genotype of the ewe. In fact, oocytes from $<1 \mathrm{~mm}$ follicles of $\mathrm{Fec}^{\mathrm{B}}$ gene carriers were able to resume meiosis in higher percentages than those from non-carriers. They also found that the pattern of oocyte growth in preantral follicles was related to the genotype and that $\mathrm{Fec}^{\mathrm{B}}$ carriers had larger oocytes than those from noncarriers. Our data showed that in Sarda ewes the ability to resume meiosis is high from oocytes derived from $<1 \mathrm{~mm}$ follicles and may be related to the genotype of this breed. In fact the oocytes derived from these follicles, which are even smaller than those from larger follicles, are capable of being meiotically competent.

In contrast, the experiment of maturation of prepubertal oocytes indicated that oocytes derived from $<1 \mathrm{~mm}$ follicles were incapable of resuming and completing meiosis compared to adult oocytes (27 versus 70 of M II) and a higher percentage of the oocytes remained arrested at the GV and M I stage. This difference in meiotic progression may be due to the smaller oocyte diameter in prepubertal oocytes (138 versus $142 \mu \mathrm{m}$ ) probably indicating an incomplete growth phase. The acquisition of meiotic competence may be closely related to oocyte diameter because at $142 \mu \mathrm{m}$ in diameter both prepubertal and adult sheep oocytes show similar nuclear progression (79.8 versus 70.6). In fact, bovine oocytes derived from small follicles showed a low diameter of $<100 \mu \mathrm{m}$ and are unable to resume meiosis or are arrested at M I; moreover these oocytes show an intense transcriptional activity [11].

In prepubertal oocytes the lower capability to resume and complete meiosis can be due to either inefficient coupling between the somatic compartment and the oocyte that can decrease the signals involved in meiotic resumption or the lack of key molecules regulating the meiosis cycle. In fact, it has been observed that the gap junctions increase with the follicular dimensions [13]. Prepubertal oocytes have also shown a less functional coupling between the corona cell and oocytes [16]. The increase in gap junctions between somatic cells and the oocyte is also related to the follicular dimension during the folliculogenesis. Furthermore, it has been observed that growing oocytes are still engaged in high RNA synthesis that may be crucial for the production of molecules directly involved in cell cycle progression. In fact, it has been observed [3] that prepubertal ovine oocytes showed a lower $\mathrm{H} 1$ activity and a lower MPF biological activity after fusion of M II prepubertal oocytes with GV stage oocytes. Similarly it has been reported that calf oocytes had lower H1 and MAPK activities compared to adult oocytes [7]. This lower competence in prepubertal oocytes has also been observed after fertilisation and culture in vivo and in vitro up to the blastocyst stage [17].

In conclusion, these experiments showed that, contrary to observations in prepubertal sheep, a high percentage of adult oocytes derived from very small follicles are able to reach full meiotic progression. Meiotic competence may, however, be closely related to oocyte diameter in sheep.

\section{ACKNOWLEDGEMENT}

This work was supported by MURST (cofinanziamento 1998)

\section{REFERENCES}

[1] Arlotto T., Schwartz J.L., First N.L., LeibfriedRutledge M.L., Aspect of follicle and oocyte stage that affect in vitro maturation and development of bovine oocytes, Theriogenology 45 (1995) 943-956.

[2] Barnes F.L., Looney C.R., Westhusin M.E., Embryo cloning in cattle: The current state of technology, Embryo Transfer Newslett. 6 (1991) $1-6$.

[3] Bogliolo L., Leoni G., Deledda F., Ledda S., Naitana S., Maturation promoting activity of in vitro matured adult and prepubertal ovine oocytes, Proceedings of the 13th Scientific Meeting, AETE, 1997, pp. 132. 
[4] Blondin P., Sirard M.A., Oocyte and follicular morphology as determining characteristics for developmental competence in bovine oocytes, Mol. Reprod. Dev. 41 (1995) 54-62.

[5] Cogniè Y., Benoit F., Poulin N., Khatir H., Driancourt M.A., Effect of follicle size and of the $\mathrm{Fec}^{\mathrm{B}}$ Boorola gene on oocyte function in sheep, J. Reprod. Fert. 112 (1998) 379-386.

[6] Crozet N., Ahmed-Ali M., Dubos M.P., Developmental competence of goat oocytes from follicles of different size categories following maturation, fertilization and culture in vitro, J. Reprod. Fert. 103 (1995) 293-298.

[7] Damiani P., Fissore R.A., Duby R.T., Biochemical and physiological maturation of cow and calf oocytes, Theriogenology 49 (1998) 310.

[8] De Smedt V., Crozet N., Gall L., Morphological and functional changes accompanying the acquisition of meiotic competence in ovarian goat oocyte, J. Exp. Zool. 269 (1994) 128-139.

[9] Duby R.T., Damiani P., Looney C.R., Fissore R.A., Robl J.M., Prepuberal calves as oocyte donors: promises and problems, Theriogenology 45 (1996) 121-131.

[10] Edwards R.G., Maturation in vitro of mouse, sheep, cow, pig, rhesus monkey and human ovarian oocytes, Nature 208 (1965) 349-351.

[11] Fair T., Hyttel P., Greve T., Bovine oocyte diameter in relation to maturational competence and trascriptional activity, Mol. Reprod. Dev. 42 (1995) 437-442.

[12] Fleming A.D., Evans G., Walton E.A., Armstrong D.T., Developmental capacity of rat oocytes matured in vitro in defined medium, Gamete Res. 12 (1985) 255-263.

[13] Herlands R., Schultz R., Regulation of mouse growth: probable nutritional role for intercellular communication between follicle cells and oocytes in oocyte growth, J. Exp. Zool. 229 (1984) 317-325.

[14] Hyttel P., Fair T., Callesen H., Greve T., Oocyte growth, capacitation and final maturation in cattle, Theriogenology 47 (1997) 23-32.

[15] Kastrop P.M.N., Bevers M.M., Destree O.H.J., Kruip A.M., Changes in protein synthesis and phosphorylation patterns during bovine oocyte maturation in vitro, J. Reprod. Fert. 90 (1990) 305-310.

[16] Ledda S., Bogliolo L., Leoni G., Calvia P., Naitana $S$., Influence of vasoactive intestinal peptide (VIP), atrial natriuretic peptide (ANP) and insulin-like growth factor-I (IGF-I) on in vitro maturation of prepubertal and adult sheep oocytes, Zygote 4 (1996) 343-348.

[17] Ledda S., Bogliolo L., Calvia P., Leoni G., Naitana S., Meiotic progression and developmental competence of oocytes collected from juvenile and adult ewes, J. Reprod. Fert. 109 (1997) 73-78.

[18] Leibfried M.L., Bavister B.D., Fertilizability of in vitro matured oocytes from golden hamster, J. Exp. Zool. 226 (1983) 481-485.

[19] Lonergan P., Monaghan P., Rizos D., Boland M.P., Gordon I., Effect of follicle size on bovine oocyte quality and development competence following maturation, fertilization, and culture in vitro, Mol. Reprod. Dev. 37 (1994) 48-53.

[20] Martino A., Paramio M.T., Mogas T., Palomo M.J., Meiotic competence of prepubertal goat oocytes, in: Proceedings of the 12th International Congress on Animal Reproduction, The Hague, 1992 , pp. $360-362$.

[21] Moor R.M., Trounson A.O., Hormonal and follicular factors affecting maturation of sheep oocytes in vitro and their subsequent developmental capacity, J. Reprod. Fert. 49 (1977) 101-109.

[22] Moor R.M., Crosby I.M., Protein requirements for germinal vesicle breakdown in ovine oocytes, J. Embryol. Exp. Morphol. 94 (1986) 207-220.

[23] Motlik J., Crozet N., Fulka J., Meiotic competence in vitro of pig oocytes isolated from early antral follicles, J. Reprod. Fert. 72 (1984) 323-328.

[24] Motlik J., Kopecnỳ V., Travnik P., Pivko J., RNA synthesis in pig follicular oocytes. Autoradiographic and cytochemical study, Biol. Cell 50 (1984) 229236.

[25] OBrien J.K., Dwarte D., Ryan J.P., Maxwell W.M.C., Evans G., Developmental capacity, energy metabolism and ultrastructure of mature oocytes from prepubertal and adult sheep, Reprod. Fertil. Dev. 8 (1996) 1029-1037.

[26] Presicce G.A., Jiang S., Simkin M., Zhang L., Looney C.R., Godke R.A., Yang X., Age and hormonal dependence of acquisition of oocyte competence for embryogenesis in prepubertal calves, Biol. Reprod. 56 (1997) 386-392.

[27] Revel F., Mermillod P., Peynot N., Renard J.P., Heyman Y., Low developmental capacity of in vitro matured and fertilized oocytes from calves compared with that of cows, J. Reprod. Fert. 103 (1995) 115-120.

[28] Szollosi D., Oocyte maturation, in: Thibault M., Levasseur C., Hunter R.H.F. (Eds.), Reproduction in Mammals and Man, Edition Marketing, Paris, 1993, pp. 307-325.

[29] Thibault C., Are follicular maturation and oocyte maturation independent processes?, J. Reprod. Fert. 51 (1977) 159-164.

[30] Thibault C., Szollosi D., Gerard M., Mammalian oocyte maturation, Reprod. Nutr. Dev. 27 (1987) 885-896. 